\title{
Controlled Temperature Plain Cement Concrete
}

\author{
S.Rajesh, Sathish Kumar K, Anish C
}

\begin{abstract}
This study attempts to compare the strength between normal concrete and controlled temperature concrete. Concrete cubes are prepared with normal and cold temperature water to know and compare the compressive strength between them. Concrete cylinders are prepared with normal and cold temperature water to know and compare the tensile strength between them. Temperature controlled concrete are more use full in heavy machinery areas which is proved by comparison of compressive strength and tensile strength between temperature controlled concrete and conventional concrete.
\end{abstract}

\section{Keywords - Normal concrete, Compressive Strength.}

\section{INTRODUCTION}

Controlled temperature concrete is a construction of concrete under controlled temperature below 20 Degree C. This type of controlled temperature concrete is mainly implemented to defuse the cracks obtained in the concrete structure[1]-[5]. These types of concretes are preferred to be stronger than conventional concrete. They are mainly used for the foundation of machineries where heavy loaded and movement created by machines mainly turbine in power plants. Turbine power plants Concrete is broadly being used in the construction industry curtains the world. A lot of research work has been ready on deeds of temperature controlled concrete all over the world however there is still a need of further evaluation chiefly in hot climate. Concrete creates warm as the cementitious material hydrate and for meager segments; heat scatters nearly as fast as is produced. In the event of gigantic structures, temperature increments because of age of more warmth of hydration subsequently the board of solid temperatures is important to avert harms, limit deferrals and meet particulars[6]-[10].

Portland concrete comprises of a few complex concoction mixes. In the arrangement of cement, the concrete goes about as glue which bonds together the aggregates to achieve the preceding cast thing. The burly achieves its quality through a faction of device reactions, known as hydration, which are begin by the development of water to the unit. The pace of the reactions impacts the properties of the set concrete, for instance, quality, permeability, sturdiness, scratched spot hindrance and insurance from cementing and defrost. For whatever period of time that water is handy, the hydration will

Revised Manuscript Received on October 22, 2019.

S.Rajesh, Department of Civil Engineering, Bharath Institute of Higher Education and Research, Chennai , India. Email: rajeshskr06@gmail.com Sathish Kumar K, Department of Civil Engineering, Bharath Institute of Higher Education and Research, Chennai , India. Email: sathish_4549@yahoo.co.in

Anish C, Department of Civil Engineering, Bharath Institute of Higher Education and Research, Chennai , India. Email: anishdavidpaul@gmail.com persist for quite a while. The last scenery of the burly molded in the route will depend upon the constituents in the main mix, and the earth under which the reactions occur[11]-[16].

\section{A. Need for Study}

To control the temperature in mass concrete. Lately brutal crack in several of the pile cap of bridges pier in southern highway project in Sri Lanka is report. once the intensive investigation it was concluded that main cause for cracking was those pile cap delayed effisite creation (DEF).The crack mold of damage concrete owed to DEF is casual.

During the process of concrete mix there will be a reaction occurs between cement, fine aggregate, coarse aggregate with normal water. During the merge of concrete heat is produced up to 30 degree $\mathrm{c}$. This high temperature might form cracks on the concrete structure in future. Hence we reduce the temperature by mixing the cement, fine aggregate, coarse aggregate with cold water in 2 degree c. It increases from 2 degree $\mathrm{c}$ to 18 degree $\mathrm{c}$ during this mixing process of concrete. This type of temperature control concrete makes the concrete to be more compressed and better than conventional concrete[17]-[25].

\section{B. OBJECTIVE}

- To know the importance of controlling the temperature in concrete.

- To know the maximum strength that temperature controlled concrete can attain.

- To contrast the compressive strength between conventional concrete and controlled temperature concrete. Compression test has to be done on 7 th day,14th day, 28th day.

\section{EXPERIMENTAL RESULTS}

Table - 1 Tests on Cement

\begin{tabular}{|l|l|}
\hline \multicolumn{2}{|c|}{ CEMENT } \\
\hline Test & Value \\
\hline Specific Gravity & 3.15 \\
\hline Fineness & $98.067 \%$ \\
\hline Consistency & $35 \%$ \\
\hline Initial Setting Time & $45 \mathrm{~min}$ \\
\hline
\end{tabular}


Table - 2 Tests on Fine Aggregate

\begin{tabular}{|l|l|}
\hline \multicolumn{2}{|l|}{ FINE AGGREGATE } \\
\hline Test & Value \\
\hline Specific Gravity & 2.62 \\
\hline Gradation & Zone III \\
\hline
\end{tabular}

Table - 3 Tests on Coarse Aggregate COARSE AGGREGATE

\begin{tabular}{|l|l|}
\hline Test & Value \\
\hline Specific Gravity & 2.68 \\
\hline Impact Value & $14.09 \%$ \\
\hline Crushing Values & $20.47 \%$ \\
\hline Abrasion Value (Los Angeles) & $5 \%$ \\
\hline
\end{tabular}

Table - 4 Tests on Fresh Concrete

\begin{tabular}{|l|l|}
\hline \multicolumn{2}{|l|}{ FRESH CONCRETE } \\
\hline Test & Values \\
\hline Slump value & $27 \mathrm{~cm}$ \\
\hline Compacting value & $0.85 \%$ \\
\hline
\end{tabular}

Table - 5 Tensile test on conventional concrete cylinder

\begin{tabular}{|c|c|c|c|c|}
\hline S.NO & $\begin{array}{l}\text { SIZE OF } \\
\text { CYLINDER } \\
(\mathrm{mm})\end{array}$ & $\begin{array}{l}7^{\text {th }} \text { DAYS } \\
(\mathrm{N} / \mathbf{m m} 2)\end{array}$ & $\begin{array}{l}14^{\text {th }} \text { DAYS } \\
\text { (N/mm2) }\end{array}$ & $\begin{array}{l}28^{\text {th }} \text { DAYS } \\
\text { (N/mm2) }\end{array}$ \\
\hline 1 & $\mathrm{D}=150 \mathrm{~L}=300$ & 2.31 & 2.68 & 3.39 \\
\hline 2 & $\mathrm{D}=150 \mathrm{~L}=300$ & 2.20 & 2.56 & 3.25 \\
\hline 3 & $\mathrm{D}=150 \mathrm{~L}=300$ & 2.34 & 2.65 & 3.30 \\
\hline AVERAGE & & 2.28 & 2.63 & 3.31 \\
\hline
\end{tabular}

Table -6 Tensile test on controlled temperature concrete

\begin{tabular}{|c|c|c|c|c|}
\hline \multicolumn{5}{|c|}{ cylinder } \\
\hline S.NO & $\begin{array}{l}\text { SIZE OF } \\
\text { CYLINDER } \\
(\mathrm{mm})\end{array}$ & $\begin{array}{l}7^{\text {th }} \text { DAYS } \\
(\mathrm{N} / \mathrm{mm} 2)\end{array}$ & $\begin{array}{l}14^{\text {th }} \text { DAYS } \\
\text { (N/mm2) }\end{array}$ & $\begin{array}{l}28_{m}^{\text {th }} \text { DAYS } \\
(\mathrm{N} / \mathrm{mm} 2)\end{array}$ \\
\hline 1 & $\mathrm{D}=150 \quad \mathrm{~L}=300$ & 2.33 & 2.71 & 3.57 \\
\hline 2 & $\mathrm{D}=150 \mathrm{~L}=300$ & 2.29 & 2.80 & 3.60 \\
\hline 3 & $\mathrm{D}=150 \mathrm{~L}=300$ & 2.35 & 2.78 & 3.55 \\
\hline AVERAGE & & 2.32 & 2.76 & 3.57 \\
\hline
\end{tabular}

II. RESULT AND DISCUSSION

Table - 7 Compressive test on controlled temperature concrete cubes

\begin{tabular}{|c|c|c|c|c|}
\hline S.NO & $\begin{array}{c}\text { SIZE OF CUBE } \\
(\mathbf{m m})\end{array}$ & $\begin{array}{c}7^{\text {th }} \text { DAYS } \\
(\mathbf{N} / \mathbf{m m} 2)\end{array}$ & $\begin{array}{c}\mathbf{1}^{\text {th }} \text { DAYS } \\
(\mathbf{N} / \mathbf{m m} 2)\end{array}$ & $\begin{array}{c}\mathbf{2 8}^{\text {th }} \text { DAYS } \\
(\mathbf{N} / \mathbf{m m} \mathbf{2})\end{array}$ \\
\hline $\mathbf{l}$ & $150 \times 150 \times 150$ & 15.26 & 34.88 & 34 \\
\hline $\mathbf{2}$ & $150 \times 150 \times 150$ & 17.44 & 37.06 & 40.11 \\
\hline $\mathbf{3}$ & $150 \times 150 \times 150$ & 16.13 & 34.44 & 44.03 \\
\hline AVERAGE & & $\mathbf{1 6 . 2 8}$ & $\mathbf{3 5 . 4 6}$ & $\mathbf{3 9 . 3 8}$ \\
\hline
\end{tabular}

Table - 8 Compressive strength on conventional concrete cube

\begin{tabular}{|c|c|c|c|c|}
\hline S.NO & $\begin{array}{c}\text { SIZE OF CUBE } \\
(\mathbf{m m})\end{array}$ & $\begin{array}{c}\mathbf{7}_{\mathrm{m}}^{\text {th }} \mathbf{D A Y S} \\
(\mathbf{N} / \mathbf{m m} \mathbf{2})\end{array}$ & $\begin{array}{c}\mathbf{1 4}_{\mathrm{m}}^{\text {th }} \\
(\mathbf{N} / \mathbf{m m} 2)\end{array}$ & $\begin{array}{c}\mathbf{2 8}_{m}^{\text {th }} \text { DAYS } \\
(\mathbf{N} / \mathbf{m m} 2)\end{array}$ \\
\hline $\mathbf{l}$ & $150 \times 150 \times 150$ & 17 & 22.05 & 25 \\
\hline $\mathbf{2}$ & $150 \times 150 \times 150$ & 16.03 & 21.06 & 23.4 \\
\hline $\mathbf{3}$ & $150 \times 150 \times 150$ & 15.01 & 39.63 & 24.2 \\
\hline AVERAGE & & $\mathbf{1 6 . 1 3}$ & $\mathbf{2 7 . 7 3}$ & $\mathbf{2 4 . 2}$ \\
\hline
\end{tabular}

Figure - 1 Graphical demonstration of compressive strength between conventional and temperature controlled concrete cube[26]-[28].

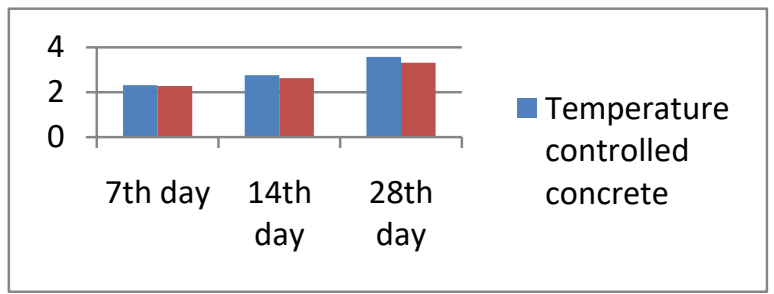

Figure - 2 Graphical demonstration of compressive strength between conventional and temperature controlled concrete cube.

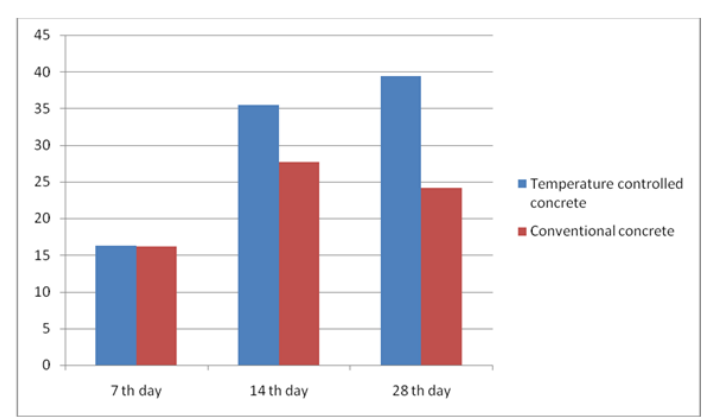

\section{DISCUSSION}

1. Maximum strength of temperature controlled concrete at 28 th day for $\mathrm{m} 25$ designed concrete is $39.38 \mathrm{~N} / \mathrm{mm} 2$.

2. At 28th day compressive strength of temperature controlled concrete is higher than conventional concrete[34].

3. At 28th day tensile strength of temperature controlled concrete is higher than conventional concrete.

\section{CONCLUSION}

The following conclusions have been drawn from the study:

1. Temperature controlled concrete has more strength as compared to conventional concrete on both tensile and compressive. 
2. It is confirmed that temperature controlling can delay the cracks formation.

3. Temperature controlled concrete is more useful for heavy working area.

\section{REFERENCES}

1. Iyappan L., Dayakar P., Identification of landslide prone zone for coonoortalukusing spatial technology, International Journal of Applied Engineering Research,V-9,I-22,PP-5724-5732,Y-2014.

2. Kumar J., Sathish Kumar K., Dayakar P.,Effect of microsilica on high strength concrete, International Journal of Applied Engineering Research,V-9,I-22,PP-5427-5432,Y-2014.

3. Dayakar P., Vijay Ruthrapathi G., Prakesh J., Management of bio-medical waste, International Journal of Applied Engineering Research,V-9,I-22,PP-5518-5526,Y-2014.

4. Swaminathan N., Dayakar P., Resource optimization in construction project, International Journal of Applied Engineering Research,V-9,I-22,PP-5546-5551,Y-2014.

5. Venkat Raman K., Dayakar P., Raju K.V.B.,An experimental study on effect of cone diameters in penetration test on sandy soil, International Journal of Civil Engineering and Technology,V-8,I-8,PP-1581-1588,Y-2017.

6. Saritha B., Chockalingam M.P.,Photodradation of malachite green DYE using TIO2/activated carbon composite,International Journal of Civil Engineering and Technology,V-8,I-8,PP-156-163,Y-2017

7. Shendge R.B., Chockalingam M.P., Saritha B., Ambica A.,Swat modelling for sediment yield: A case study of Ujjani reservoir in Maharashtra, India,International Journal of Civil Engineering and Technology,V-9,I-1,PP-245-252,Y-2018

8. Chockalingam M.P., Balamurgan V.,Modernisation of an existing urban road-sector in Chennai, a case study report,International Journal of Civil Engineering and Technology,V-8,I-8,PP-1457-1467,Y-2017

9. Saritha B., Chockalingam M.P.,Adsorption study on removal of basic dye by modified coconut shell adsorbent, International Journal of Civil Engineering and Technology,V-8,I-8,PP-1370-1374,Y-2017

10. Saritha B., Chockalingam M.P.,Adsorptive removal of heavy metal chromium from aqueous medium using modified natural adsorbent,International Journal of Civil Engineering and Technology,V-8,I-8,PP-1382-1387,Y-2017

11. Chockalingam M.P., Palanivelraja S.,Retrospective analysis of a theoretical model used for forecasting future air quality near the north Chennai thermal power plant,International Journal of Civil Engineering and Technology,V-8,I-8,PP-1457-1467,Y-2017

12. Saritha B., Chockalingam M.P.,Photodegradation of methylene blue dye in aqueous medium by $\mathrm{Fe}-\mathrm{AC} / \mathrm{TiO} 2$ Composite,Nature Environment and

Pollution Technology,V-17,I-4,PP-1259-1265,Y-2018

13. Shendge R.B., Chockalingam M.P., Kaviya B., Ambica A.,Estimates of potential evapotranspiration rates by three methods in upper Bhima Basin, In Maharashtra, India,International Journal of Civil Engineering and Technology,V-9,I-2,PP-475-480,Y-2018

14. Shendge R.B., Chockalingam M.P.,The soil and water assessment tool for Ujjani Reservoir,International Journal of Mechanical Engineering and Technology,V-9,I-2,PP-354-359,Y-2018

15. Shendge R.B., Chockalingam M.P.,A review on soil and water assessment tool,International Journal of Mechanical Engineering and Technology,V-9,I-2,PP-347-353,Y-2018

16. Sachithanandam P., Meikandaan T.P., Srividya T.,Steel framed multi storey residential building analysis and design,International Journal of Applied Engineering Research,V-9,I-22,PP-5527-5529,Y-2014

17. Meikandaan T.P., Ramachandra Murthy A.,Study of damaged RC beams repaired by bonding of CFRP laminates,International Journal of Civil Engineering and Technology,V-8,I-2,PP-470-486,Y-2017

18. Meikandaan T.P., Ramachandra Murthy A.,Retrofittng of reinforced concrete beams using GFRP overlays,International Journal of Civil Engineering and Technology,V-8,I-2,PP-423-439,Y-2017

19. Meikandaan T.P., Ramachandra Murthy A.,Flexural behaviour of RC beam wrapped with GFRP sheets,International Journal of Civil Engineering and Technology,V-8,I-2,PP-452-469,Y-2017

20. Meikandaan T.P., Murthy A.R.,Experimental study on strengthening of rc beams using glass Fiber,International Journal of Civil Engineering and Technology,V-9,I-11,PP-959-965,Y-2018

21. Meikandaan T.P., Hemapriya M.,Use of glass FRP sheets as external flexural reinforcement in RCC Beam,International Journal of Civil Engineering and Technology,V-8,I-8,PP-1485-1501,Y-2017
22. Saraswathy R., Saritha B.,Planning of integrated satellite township at Thirumazhisai,International Journal of Applied Engineering Research,V-9,I-22,PP-5558-5560,Y-2014

23. Saritha B., Ilayaraja K., Eqyaabal Z.,Geo textiles and geo synthetics for soil reinforcement,International Journal of Applied Engineering Research,V-9,I-22,PP-5533-5536,Y-2014

24. Ambica A., Saritha B., Changring G., Singh N B., Rajen M., Salman Md.,Analysis of groundwater quality in and around Tambaram taluk, Kancheepuram district,International Journal of Civil Engineering and Technology,V-8,I-8,PP-1362-1369,Y-2017

25. Arunya A., Sarayu K., Ramachandra Murthy A., Iyer N.R.,Enhancement of durability properties of bioconcrete incorporated with nano silica,International Journal of Civil Engineering and Technology,V-8,I-8,PP-1388-1394,Y-2017

26. Ilayaraja K., Krishnamurthy R.R., Jayaprakash M., Velmurugan P.M., Muthuraj S.,Characterization of the 26 December 2004 tsunami deposits in Andaman Islands (Bay of Bengal, India),Environmental Earth Sciences, V-66,I-8,PP-2459-2476,Y-2012

27. Ilayaraja K.,Morphometric parameters of micro watershed in Paravanar sub-basin, Cuddalore District,International Journal of Civil Engineering and Technology,V-8,I-8,PP-1444-1449,Y-2017

28. Ilayaraja K., Singh R.K., Rana N., Chauhan R., Sutradhar N.,Site suitability assessment for residential areas in south Chennai region using remote sensing and GIS techniques, International Journal of Civil Engineering and Technology,V-8,I-8,PP-1468-1475,Y-2017

29. Ilayaraja K., Reza W., Kumar V., Paul S., Chowdhary R.,Estimation of land surface temperature of Chennai metropolitan area using Landsat images,International Journal of Civil Engineering and Technology,V-8,I-8,PP-1450-1456,Y-2017

30. Chitra R.,Experimental study on beam using steel fiber and latex,International Journal of Civil Engineering and Technology,V-8,I-8,PP-1395-1403,Y-2017

31. Chitra R.,Analysis of traffic and management at Kovilambakkam intersection,International Journal of Civil Engineering and Technology,V-8,I-8,PP-1433-1443,Y-2017

32. Aswathy M.,Experimental study on light weight foamed concrete,International Journal of Civil Engineering and Technology,V-8,I-8,PP-1404-1412,Y-2017

33. Aswathy M.,Wastewater treatment using constructed wetland with water lettuce (Eichornia Crasipies),International Journal of Civil Engineering and Technology,V-8,I-8,PP-1413-1421,Y-2017

34. Kiruthiga K., Anandh K.S., Gunasekaran K, Assessment of influencing factors on improving effectiveness and productivity of construction engineers, 2015, International Journal of Applied Engineering Research, V - 10,I -17,p -13849-13854.

\section{AUTHORS PROFILE}

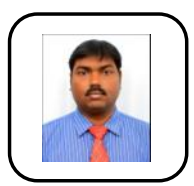

S. Rajesh Assistant Professor, Department of Civil Engineering, Bharath Institute of Higher Education and Research, Chennai, India.

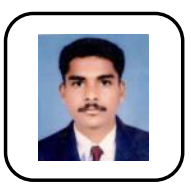

K Sathish Kumar Assistant Professor, Department of Civil Engineering, Bharath Institute of Higher Education and Research, Chennai, India.

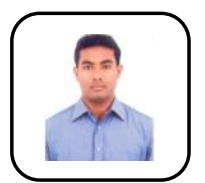

Anish C Assistant Professor, Department of Civil Engineering, Bharath Institute of Higher Education and Research, Chennai, India. 